\title{
INFLUENCE OF FINANCIAL LITERACY ON MANAGEMENT OF PERSONAL FINANCES IN A YOUNG HOUSEHOLD
}

\author{
Mykolas Navickas ${ }^{1}$, Tadas Gudaitis ${ }^{2}$, Emília Krajnakova ${ }^{3}$ \\ ${ }^{1}$ ISM University of Management and Economics, E. Ožeškienès g. 18, LT-44254 Kaunas, Lithuania \\ ${ }^{2}$ International Business School at Vilnius University, Sauletekio al. 22, LT-10225 Vilnius, Lithuania \\ ${ }^{3}$ University of Alexander Dubcek in Trencin, Studentska str. 3, 91150 Trencín, Slovakia \\ E-mails: ${ }^{1}$ navimyko@stud.ism.lt (correspondingauthor); ${ }^{2}$ tadgud@gmail.com; ${ }^{3}$ emilia.krajnakova@tnuni.sk \\ Received 03 September2013; accepted 08 October 2013

\begin{abstract}
The article focuses on the importance of financial literacy to management of personal finances in a young household. Responsible management of personal finances should be fostered since early stages of life, as financial mistakes made during the years of youth can be costly and difficult to correct in the future. Moreover, a high level of financial literacy has a positive impact on day-to-day decision making and leads to higher saving rates, which improves the quality of life in the long run. The paper deals with main factors affecting the low level of financial literacy in Lithuania and other countries. Results of the survey of Lithuanian residents are compared to results of similar foreign researches.
\end{abstract}

Keywords: financial literacy, personal finance, personal finance management, young households.

JEL Classification: D100, D110, D140, D310.

\section{FINANSINIO RAŠTINGUMO İTAKA JAUNIMO ASMENINIŲ FINANSŲ VALDYMUI}

\author{
Mykolas Navickas ${ }^{1}$, Tadas Gudaitis ${ }^{2}$, Emília Krajnakova ${ }^{3}$ \\ ${ }^{1}$ ISM Vadybos ir ekonomikos universitetas, E. Ožeškienès g. 18, LT-44254 Kaunas, Lietuva \\ ${ }^{2}$ Vilniaus universiteto Tarptautinio verslo mokykla, Saulètekio al. 22, LT-10225 Vilnius, Lietuva \\ ${ }^{3}$ Alensandro Dubčeko universitetas Trenčine, Studentska g. 3, 91150 Trenčínas, Slovakija \\ El.paštas: ${ }^{1}$ navimyko@stud.ism.lt; ${ }^{2}$ tadgud@gmail.com; ${ }^{3}$ emilia.krajnakova@tnuni.sk
}

Iteikta 2013-09-03; priimta 2013-10-08

\begin{abstract}
Santrauka. Straipsnyje analizuojama finansinio raštingumo ịtaka jaunų namų ūkių asmeninių finansų valdymui. Atsakingas asmeninių finansų valdymas privalomas nuo mažų dienų. Anksti gyvenime padarytos finansinès klaidos gali kainuoti dideles sumas pinigu ir būti sunkiai ištaisomos ateityje. Be to, geros finansinio raštingumo žinios sudaro sąlygas priimti racionalesnius kasdienius sprendimus ir padeda išleisti mažiau pinigų. Žmogus sutaupo kur kas daugiau, o tai per ilgą laikotarpi gerina ir jo gyvenimo kokybę. Straipsnyje analizuojamos pagrindinès žemą finansinį raštingumą Lietuvoje ir kitose šalyse lemiančios priežastys. Atlikus Lietuvos gyventojų apklausą, gauti rezultatai lyginami su panašiais užsienio tyrèjų darbais.
\end{abstract}

Reikšminiai žodžiai: finansinis raštingumas, asmeniniai finansai, asmeninių finansų valdymas, jauni namų ūkiai.

\footnotetext{
Copyright $\odot 2014$ The Authors. Published by VGTU Press.

This is an open-access article distributed under the terms of the Creative Commons Attribution-NonCommercial 4.0 (CC BY-NC 4.0) license, which permits unrestricted use, distribution, and reproduction in any medium, provided the original author and source are credited. The material cannot be used for commercial purposes.

http://dx.doi.org/10.3846/btp.2014.04
} 


\section{Introduction}

The relevance of the study: In the last decade the concept of personal finance has been tangled a lot by famous economists such as Lusardi, A. (2008/2013); Mitchell, S. O. (2010) or by different organizations: OECD (2012), Lithuanian Bank (2012/2013) and others. The importance of personal finance management became very clear after global financial crisis in 2008. A considerable part of households faced financial difficulties, as they have lost part of their income, due to lost jobs and did not had enough savings to pay out the mortgage. The value of accumulated capital in long-term solutions has dropped significantly. E.g. OECD has estimated that the losses of pension funds in OECD countries to be 5.4 trillion USD or about $24 \%$ of the value of assets in these countries in 2008 (OECD 2011). The returns of pension funds in Latin America and Central Europe in 2008 were two-digit negative. These numbers indicate that lots of people suffered from financial crisis. Recent experience shows, that it is very important to have sufficient financial management skills and financial literacy knowledge starting from the young age. These financial planning mistakes done in the first stages of independent life can be difficult to be corrected in the future, so their financial decision making has high impact not only on their current household economic well-being, but also influence the future. These are the main reasons why the subject of the article is young households aged between 18 and 30. Young households in Lithuania combine almost $1 / 3$ of a population in Lithuania (Lithuanian Department of Statistics 2013). In the paper it will analyze what other effects financial literacy does to personal finance management. Moreover, it will be discussed how financial literacy level can be improved.

\section{The novelty of the study}

Almost no scientific analysis has been made in Lithuania on personal finance management and financial literacy. Authors that do work in this subject usually analyze it only partially: Vitunskienè, V. (1997) analyzed households' economics; Rakauskienè, O. G., et al. (2007) investigated saving behavior models of different genders; Bikas, E., et al. (2010) researched behavior of investors. Financial supervisory authorities are starting to pay much more attention on the financial literacy education, main issues related with personal finance planning (e.g. setting minimal own capital criteria's for lending, supervising quick (or fast) short-term lending products supervisory; benchmarking investment management of investment risk of private second and third pillar pension funds, etc.), starting public PR and marketing campaigns on financial literacy education. This shows the mean that responsible management of personal finance and saving from the early stage of life inevitable. Authors of the paper did not find any similar study which was made about Lithuanian young households. The research analysis young Lithuanian people approach towards various saving ways and the results will be compared with similar foreign researches.

The object of the paper is personal finance management and the importance of financial literacy in Lithuanian population part between 18 and 30 years old.

The aim of the study is to define the main concepts and importance of personal finance management and financial literacy using comparable analysis of the scientific literature. Also to examine the level of financial literacy and personal finance management skills of young (18 to 30 years old) Lithuanians and compare the results with foreign countries experience.

\section{The tasks of the study are:}

1. To analyze the scientific literature in order to define the main concepts, importance of personal finance management and financial literacy.

2. To create the questionnaire based on foreign scientists researches and Lithuanian specifics, and to evaluate the level of financial literacy and personal finance management skills.

3. To survey Lithuanian population between 18 and 30 years old.

4. To compare questionnaire results with similar results of foreign researches

5. To analyze what causes the current level of financial literacy and personal finance management skills in Lithuania and what measures would increase its 'level.

The methods of research are: systematic, logical and comparative analysis of literature and generalized statistical data that was collected in online survey using descriptive Lithuanian population statistics.

\section{Theoretical background}

In this part authors analyze significance of others researches that examined concept of personal finance management and financial literacy. Also shows the importance of these factors in everyday life and describes the methods that were used for analyzing practical research.

\subsection{The concepts and understanding of personal finance management}

Analyzing the concept of personal finance it is easy to encounter various approaches towards this subject, as there are lots of authors that study this theme (see Table 1).

Analyzing these various concepts and models authors can come to the conclusion that most of the authors use one theoretical approach towards management of personal 
finance (ex. only incomes and expenditures, only savings, etc.) and there is no systematic attitude towards this approach.

As Klimavičienè and Jurevičienė (2008) suggests, we can contract all the approaches to one fundamental equation and name personal finance simply as (Fig. 1).

There are lots of definitions by various authors, but we could simply call personal finance as all financial decisions and activities that a person could make. This could include

Table 1. Approaches to personal finances (according to Lithuanian Department of Statistics 2013; Lusardi 2008; Rakauskiene, Bikas 2007; van Rooij et al. 2011; Klimavičiené, Jurevičienè 2008; Charupat et al. 2012; Gambacorta, Marques-Ibanez 2011)

\begin{tabular}{|l|l|}
\hline \multicolumn{1}{|c|}{ Approach } & \multicolumn{1}{c|}{ Researchers } \\
\hline $\begin{array}{l}\text { Households incomes } \\
\text { and expenditure }\end{array}$ & Lithuanian Department of Statistics \\
\hline Saving & $\begin{array}{l}\text { Lusardi, A.; Rakauskiene, O. G.; } \\
\text { Bikas, E., banks }\end{array}$ \\
\hline Planning & $\begin{array}{l}\text { van Rooij, M.; Lusardi ,A.; Alessie, R.; } \\
\text { Jurevičiené, D.; Klimavičiené, A. }\end{array}$ \\
\hline Investing & Financial Institutions, Bikas, E. \\
\hline Lifecycle & $\begin{array}{l}\text { Charupat, N.; Huang, H.; } \\
\text { Milevsky, M. A. }\end{array}$ \\
\hline Lending & Gambacorta, L.; Marques-Ibanez, D. \\
\hline
\end{tabular}

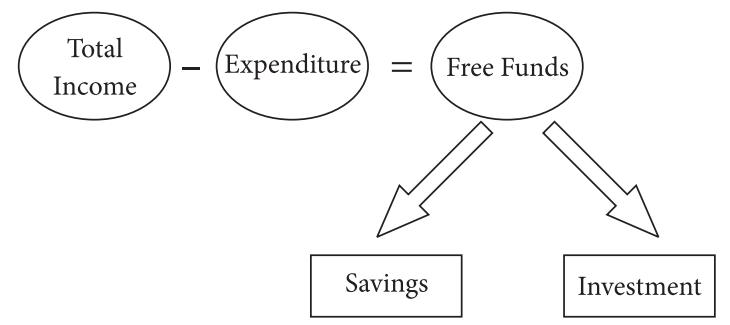

Fig. 1. Equation of personal finance (Klimavičienè, Jurevičienè 2008) budgeting household incomes and expenditures, savings, investments, mortgages, insurance and all other decisions that require money. The most important factor of personal finance management is financial planning, which should involve analyzing the financial position and setting of shortterm and long-term goals. In Lithuanian, as well as other countries 'case, this might be future retirement fund, children education fund, etc. But for all this, there is a need of financial literacy, which would help understand various financial services and make financial decisions. Looking into all the approaches towards personal finance might seem complicated for an individual without financial education, as such person usually does not understands the way of managing (planning, saving, investing and borrowing if needed) money. Model (see Fig. 1) simplifies all the approaches and might help individuals manage these processes without intermediaries (such as financial institutions, etc.) intervention. It could be simple and easy way to raise public awareness to the significance of personal finance. It is important to have good skills of personal finance management in order to make correct day-to-day decisions such as what to buy, what not buy. This would help to save lots of money in the long run, as unnecessary products would be bought not so frequently. It would also help dealing with financial services, as even $34 \%$ of Lithuanian population does not look for other alternatives, while searching for financial services (Bank of Lithuania research 2012). Ability to make these decisions more responsibly would improve the wellbeing of the households. The reality is that the problem of irresponsible personal finance management is relevant not only in Lithuania, but all across the world.

Figure 2 shows that the financial knowledge still can be greatly improved even in such developed countries as Germany or Norway.

One of the best ways to increase personal finance management skills is to track a budget and fix all the incomes and expenses for each period (e.g. month, quarter, etc.). This would also help to avoid unreasonable purchases and

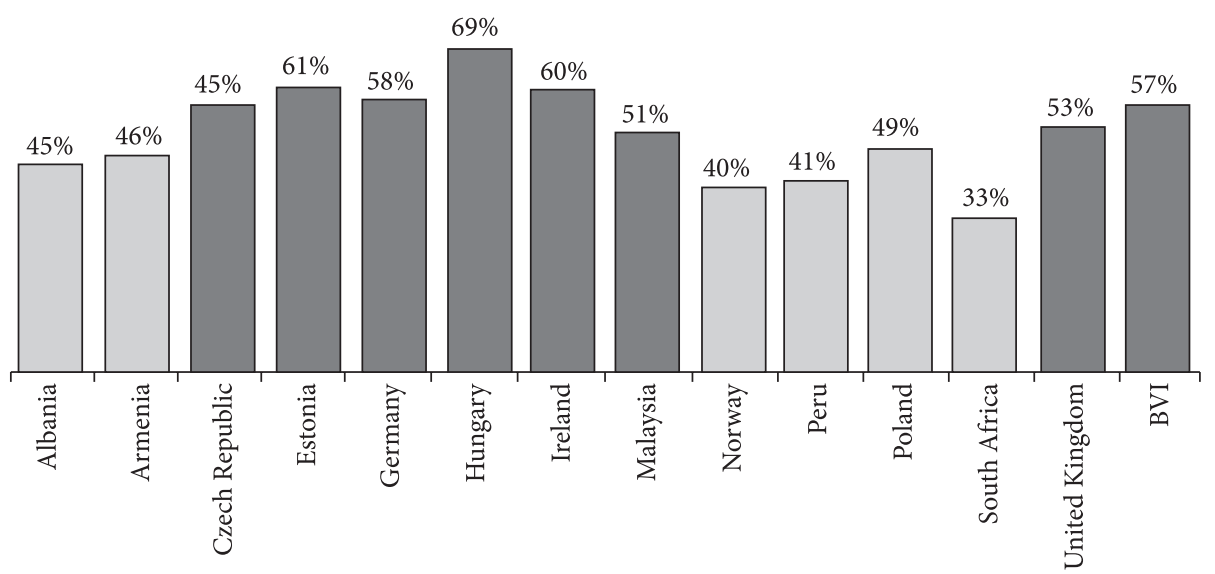

Fig. 2. Countries with high financial knowledge points (Atkinson, Messy 2012) 
save more money for investments. The research in the article will reflect percentages of Lithuanian households that follow their budgets.

\subsection{Financial literacy's role in the well-being of households}

Financial literacy is very important in each household for day-to-day decision making, as it helps saving money, which later could be invested or saved for reaching goals that have been set.

This includes simple decisions, such as: where to buy fast moving consumer goods, what type of investment risk pension fund to select, etc. But it might be beneficial not only for individuals or households, but also for countries' economic system. However, it is easy to observe that most of the households lack financial literacy. This concerns not only governments, but also various researchers e.g. Lusardi, A. (2008); Marcolin, S.; Abraham, A. (2006). Exchairman of USA Federal Reserve Alan Greenspan once said: "The number one problem in today's generation and economy is the lack of financial literacy. After logical and systematic analysis of scientific researches authors can agree to the conclusions, that financial literacy is too low in the larger part of households across the globe - Lithuania is not an exception. Based on Lithuanian public opinion research results in 2009 (when 1006 respondents from 18 to 75 years were questioned) Lithuanian society also lacks financial literacy (Spinter Tyrimai 2009). In order for households to make day-to-day decisions correctly they should know the basic concepts of personal finance, such as: compound interests, investment risk and its management during short and long term periods (e.g. eliminating risk while approaching retirement age). Understanding these concepts would help to eliminate most frequent incorrect decisions (e.g. investing into wrong financial instruments, pension, mutual funds, etc.) Investing into foreign stocks or bond markets, mutual or hedge funds at the acceptable and understandable investment risk level could be great example how in the long run responsible management of personal finances brings more money into economy, which leads to higher spending and raises GDP. What is more, individuals' decisions affect countries well-being by adjusting the interest rates and inflation. Responsible management of financial resources is beneficial not only for households, but also for the whole country. In order to make correct decisions appropriate level of financial literacy is needed. E.g. in 2002 Lithuania started pension system reform, by establishing $2^{\text {nd }}$ pillar pension funds. However, the long term financial resources for funding 2 nd pillar were not planned properly. During financial crisis the premiums to 2 nd pillar pension funds were reduced (see Gudaitis 2009 for details) and it is still not restored to the previously planned levels. Social Insurance agency („SoDra“) debt has already reached 10, 3 billion Litas. Such big debt comparing to total Lithuanian debt might lead to enormous pension cuts for future retirees, so responsible hoarding of money and financial planning for future old-age pension is inevitable. The role and importance of financial literacy leads to a lot of discussions about management of personal finance and there are a lot of authors both inside and outside Lithuania that contributed to this field of work, such as: Annamaria Lusardi (2010), Olivia S. Mitchell, Luigi Guiso, Maarten van Rooij, Aušra Klimavičienè (2008), Daiva Jurevičienė (2008) and others.

\subsection{Methods of research}

Even though there has been much debated about personal finances and financial literacy in Lithuania (e.g. Rakauskienè, O. G. and Bikas, E. (2007); Bikas, E. and Kavaliauskas, A. (2010)), not much empirical researches has been done on the topic of the article. Research methods that have been used by Ruškyte, D. et al. (2013) can be also used while researching young households. The authors aim - to examine the level of financial literacy and personal finance management skills of young (18 to 30 years old) Lithuanians and compare the results with foreign countries experience, such as Estonia, Poland, Hungary, Czech Republic and developed western countries such as Germany and USA. The questionnaire formed for this research has been analyzed using descriptive statistics. Respondents have been selected using random sample. Findings of this examination have been compared to the results of two other researches: Atkinson, A. and Messy, F. (2012), Lusardi et al. (2010).

\section{Research results}

Method used for research is online survey, as it helps to reach largest audience. Online survey was placed on internet survey pool apklausa.lt. Taking into consideration that every citizen of Lithuania could fill in the questionnaire for analysis we use random sampling method. Our chosen Lithuanian population between 18 and 30 is 626 thousand citizens. Using sample calculation program authors get that for research to be statistically relevant 384 respondents is needed (437 has been surveyed.) Respondents' age varies between 18 and 30 , but $16 \%$ of sample have been over 30 years of age. Population that has been studied was also sampled randomly from various cities of Lithuania. 64\% of the sampled population was youngest households between 18 and 24 years; $20 \%$ : $25-30$ years; and $16 \%$ over 30 as mentioned before. Largest part of respondents consists from cities of two biggest cities in Lithuania: Vilnius and Kaunas ( $65 \%$ of all respondents). 


\subsection{Households budgeting}

Every person or household that have money coming in usually also faces responsibilities that come with independent life. Most of the households have to pay bills such as rent or mortgage, buy food and has other daily life expenses. There are two basic principles why conduction of a budget is important. Firstly, it shows whether you are spending more that earning and secondly how much can you allow to spend on various items. Crucial part of budgeting - to have a goal in mind (e.g. paying out mortgage quickly, new car, retirement fund, etc.) as it helps physiologically and gives more control to consumer on his day-to-day decisions. However, it is not always easy to follow a budget, as professional marketing can make high impact on individuals' with lower financial literacy level decisions for higher expenditures. Not only economists have noticed and analyzed the importance of budgeting (Barigozzi et al. 2009) but also participants of the financial sectors such as service providers or supervisory authorities.

A lot of various budget management programs have been implemented, such as BudgetPulse, Serenic and others, but most of them are concentrated towards American society and almost unused in Europe. In Lithuania, biggest retail banks (e.g. SEB bank, Swedbank) also try to implement tools in their electronic banking systems, dedicated for their clients to control household budgets. As the results of the research shows, only $32 \%$ of our sampled population tracks their budget, even though average income of examined population is $\sim 1700 \mathrm{Lt} /$ month after taxes, which almost equals Lithuanian average $(1731 \mathrm{Lt}$ after taxes) and even $\sim 58 \%$ of the sampled population earn below average wage of Lithuania, they still do not budget to their income. And according to OECD research in 2012 a lot of member states have the same problem (see Fig. 3). In order to increase number of households that budgets their money, level of financial literacy in Lithuania and OECD countries has to be raised. With a support of government, banks in Lithuania try to upgrade this number with implementation programs mentioned before. And as Krajnakova, E. and Vojtovic, S. (2011) mentions: development of science and education has to be raised to top priorities of state. Financial literacy basic concepts have to be taught even in elementary school. This would raise society awareness to financial illiteracy and help increase its' level. So, budgeting incomes and expenditure is the most important factor of personal finance management and in order to do it correctly financial literacy knowledge is vital. Unfortunately, as research comparison shows financial literacy level is still very low both in OECD countries and Lithuania. In order to increase this number education program has to be implemented.

Not budgeting money leads to lower saving and investment rates, lowers the possibility of having retirement plans, etc. So all in all, budgeting is very important part of household personal finance management as it raises countries' competitiveness in the long run, with more money fluctuating in the economy.

\subsection{Borrowing}

After global financial crisis in 2008 government increased regulations on long term borrowing, such as mortgages or leasing. Nowadays, banks or other institutions before borrowing money must thoroughly look into individuals' financial history, to make sure that the client is solvent. But borrowing smaller amounts of money is still very easy in Lithuania, as you can do it in 5 minutes in a post office or shopping center. But the interest combined with other costs is very high (Bank of Lithuania 2012) and reaches $216 \%$, as well as insolvent clients' number. Moreover, according to Bank of Lithuania (2012), even 36\% of fast credits are

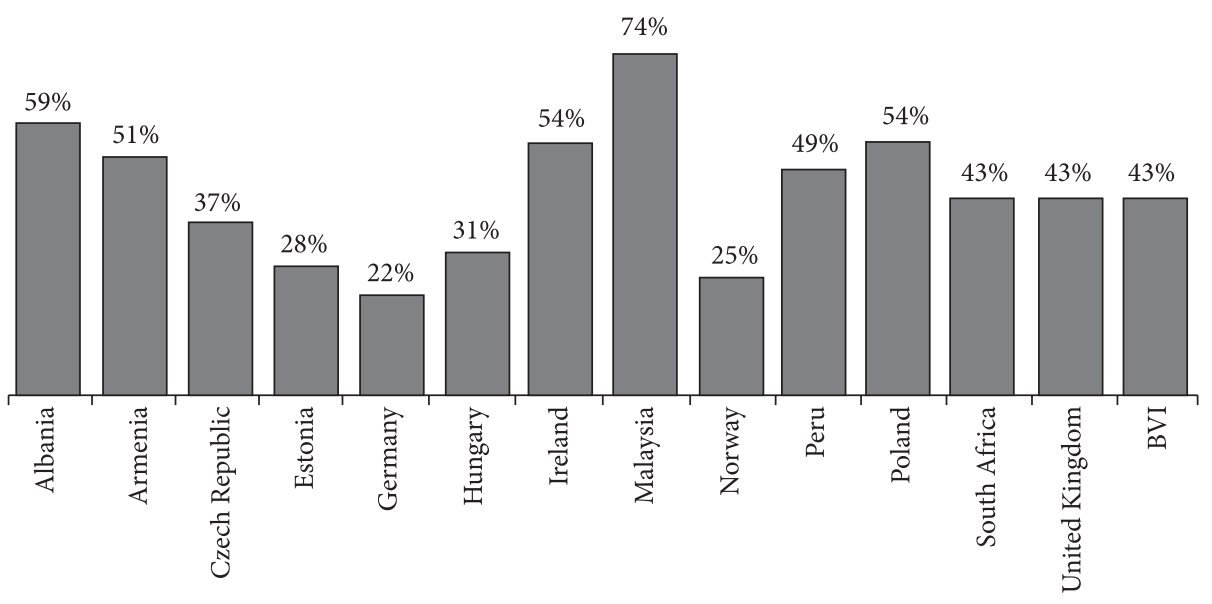

Fig. 3. Part of researched population, which has a household budget (Atkinson, Messy 2012) 


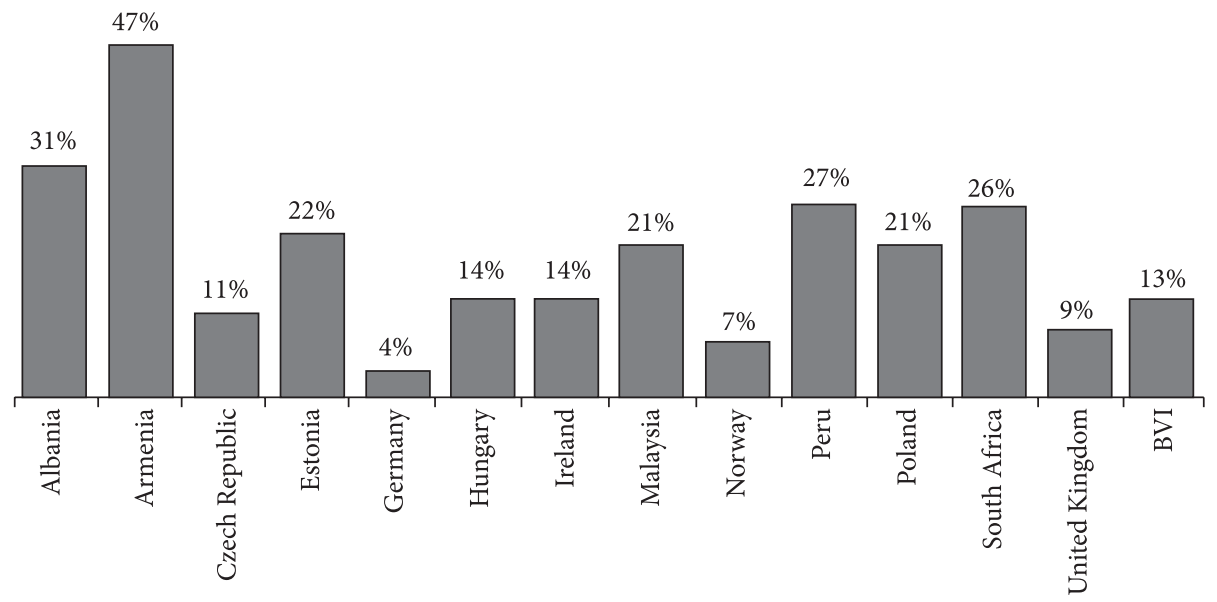

Fig. 4. Used credits to make ends meet at least once in the last 12 months (Atkinson, Messy 2012)

taken by young people up to 25 years old. These numbers shows that part of Lithuanian youth cannot manage their money responsibly and tends to take quick loans. Our research also grounds this fact, as mentioned before two thirds of sampled population does not track their budget. $6 \%$ of all the respondents at the end of month do not have enough money and borrows them. And from part that tracks their budget 19\% says that at the end of month they have balanced budget, which means, that their saving rates equals 0 . This means that this part of population has no retirement or emergency fund and might borrow money in such situations as vehicle breakdown, health problems, etc. Respondents have been asked whether they have borrowed money in the last 12 months to make ends meet. Surprisingly, even $55 \%$ have faced this problem. On the other hand, only $9 \%$ of the population used consumer or quick loans to make ends meet, while $18 \%$ used their old savings and $28 \%$ borrowed from family or friends. The numbers indicate that Lithuanian households tend to trust less in financial institutions and are more likely to borrow from friends. Authors predict that it is due to relatively high interest rates of lending products, which are offered by different financial institutions. Comparing these results to the same question asked in OECD countries shows that borrowing from financial institutions to make ends meet in Lithuania numbers are among the lowest in the world. And they are much smaller than other post-Soviet countries such as Poland or Estonia (see Fig. 4).

Even though, Lithuanian saving rates are not high, but young households tends to avoid borrowing from financial institutions and has an ability use older savings or borrow from friends and family. This indicates that when people lack money, they do have enough financial literacy to make correct decisions while borrowing money. In the long run it helps to save money for interest paid and makes positive impact on personal finance management.

\subsection{Savings and investments}

Saving is a big part of personal finance management and it requires high financial literacy skills. Lusardi, A. (2010) has indicated how important it is as people need to save money in order to have emergency and retirement funds. But saving rates are increased in the long run, when people invest in various financial instruments. Although, it requires risk, but it could be spread with investments into different sectors or even completely eliminated. Not understanding importance of investing and risk shows low level of financial literacy. Lithuanian case shows that too many people tend to hold their money in deposits (26\% of the respondents) and even more in a bank account (47\%). These numbers indicate that Lithuanian population has free money, but they hoard it instead of investing. Bank of Lithuania research (2013) indicates very similar percentages. Worth mentioning, that $\sim 25 \%$ has at least once invested in investment funds or dealt shares. But the difference between these two groups shows that investment numbers can still be improved. Larger scope of financial investment instruments can increase these numbers, as research made in Chile (2011) shows that individuals with more knowledge about the pension system are more likely to have additional financial savings. Other example could be derivatives, as only $1,4 \%$ of the sampled population uses derivatives, while it is much more popular in USA. Even $47 \%$ of population has not heard about derivatives and $21 \%$ about mutual funds. This again indicates that people lack financial literacy and knowledge about potential investment destinations. Raising public awareness about various financial instruments and their importance would definitely increase investment rates. Ability to invest correctly and gain highest returns is the most difficult part of personal finance management, as it needs very high level of financial literacy. Research indicates that investment numbers are very low in Lithuania and it must be improved. It can be 
done with various financial literacy education programs or introduction with more financial instruments.

\subsection{Financial literacy evaluation}

To measure Lithuanian financial literacy level four practical questions were constructed. Each question helps to compare results to similar questions asked by foreign researchers (Lusardi, A.; Mitchell, S. O. (2004-2013) and OECD research in 2012). Analysis of this part of the research helps to understand where specific financial literacy knowledge can be used and how it helps to manage personal finance. Every question had 3 or 4 possible answers, with addition answers of: "don't know the answer" or "don't know what these concepts mean".

Respondents were asked to calculate simple interest for 5 years deposit with interest rate calculated on the annual basis of $3 \%$ (deposit of $1000 \mathrm{Lt}$ ). $67 \%$ of sampled population answered correctly, saying that deposit will return more than $1030 \mathrm{Lt}$ after 5 years. The idea of the question was to see whether individuals understand simple concept of interest rates. In everyday decision making this helps to evaluate all possible alternatives and choose the best one, based on the highest returns.

Unfortunately, one-third of the population failed to make this calculation correctly. Similar question has been asked by Lusardi, A.; Mitchell, S. O. (2004-2013) in their research and $67 \%$ of the sampled population $(\mathrm{N}=7417)$ answered correctly. So, comparing Lithuanian and American sampled populations, authors can say that there is no difference in understanding of interest rates in these states. This indicates that the problem of low financial literacy is spread all around the world.

As our research shows, even $26 \%$ of the young age population holds their money in deposits in financial institutions such as banks, credit unions, etc. One of the most important choices while choosing deposit details is whether its' interest will be simple or compound. In the long run compound interest gives much higher returns. It is also vital while choosing retirement plans, etc. To understand the concept of compound interest individual has to have better financial literacy knowledge, but in return this might lead to much higher saving rates. To see how many people can understand the principle of compound interest we asked another question: How much money you will have after 2 years if compound interest rate is $10 \%$ and is calculated on the annual bases (deposit of $1000 \mathrm{Lt}$ )? Unfortunately, only $43 \%$ respondents answered correctly $(1210 \mathrm{Lt})$. But comparing results to similar question asked by OECD in 2012, we can see that these numbers are among the highest. Only Norway (54\%) Germany (47\%) and Hungary (46\%) has higher numbers in understand of compound interest concept, while other CEE countries such as Poland and Estonia have lower numbers of $27 \%$ and $31 \%$. These researches show that financial literacy level is very low not only in Lithuania, but also in OECD countries.

The next question was constructed to analyze whether respondents can understand basic elements about money value and inflation. They were asked does their purchasing power rises or drops if inflation is 3\% and the interest rate on their deposit $2 \%$. Surprisingly, only $60 \%$ were correct, whereas according to the same Lusardi, A.; Mitchell, S. O. (2004-2013) research 75\% of Americans were correct. So in Lithuania there is slightly lower level of understand principle of inflation. As this is one of the basic financial literacy questions it again shows that Lithuanian society lacks financial literacy and it highly influences management of personal finance. The last question required highest knowledge of financial literacy, as respondents were asked whether corporate bonds or stocks usually give higher returns in the long run. Only $44 \%$ answered correctly while saying that it is stoc$\mathrm{ks}$. What is more, from all of the respondents, which have studied, $42 \%$ has an education in areas such as management, economics, finance, mathematics, etc. So given the assumption that all of them should have been correct, then only $13 \%$ of respondents who did not study higher education or did studied in other areas were correct. Or other assumption can be raised - that even higher education in areas such as economics, management, etc. does not assure high level of financial literacy knowledge, which is even more shocking.

Each of these four questions, analyzed above provides useful information. The responses to them can also be combined to an average financial literacy score which is $53.8 \%$, which seems to be worrying. All these results indicate that financial literacy knowledge is low in young Lithuanian households. And as analyzed literature shows around the world, many people are also financially illiterate.

\section{Conclusions}

After systematic, logical and comparative analysis of literature and survey of Lithuanian population between 18 and 30 years old it is clear that financial literacy influence on personal finance management is very high. After comparison of questionnaire results with foreign authors' researches conclusion can be made that not only Lithuanian, but also OECD and USA countries lacks financial literacy. The research has shown that young households do not know the basic concepts of financial literacy, such as simple and compound interest. This effects their decision making, while choosing mortgages, leasing, bank deposits, retirement funds, etc. In the long run these decisions can combine into huge amount of money and this is the reason why financial literacy education program has to be implemented. Tendency towards inflation is also very clear-even $40 \%$ of the population does not understand how inflation affects 
their purchasing power, which is also a sign of very low financial literacy level. As results show, there is a part of Lithuanian young age society that has money to save and invest, but only $44 \%$ know the basic difference between stocks and corporate bonds, which means, that even though people have money to invest, they lack knowledge to do so. Despite all the observations made by policy-makers or researches made by scientists these is still very little done to raise the financial literacy of young households. So, lack of financial literacy means that households cannot manage their personal finance properly, spends a lot of money because of impulsive or unnecessary buying, which eventually leads to lower saving rates and lower investment returns. Moreover it might reduce countries' competitiveness in the global market in long term perspective. Countries that will introduce and improve financial literacy education programs for people of all types of age will be much better-off in the long run comparing to the countries which will not make it.

\section{References}

Atkinson, A. F.; Messy, F. 2012. Measuring Financial Literacy: Results of the OECD / International Network on Financial Education (INFE) Pilot Study, OECD Working Papers on Finance, Insurance and Private Pensions 15: 10-33.

Bank of Lithuania. 2012. Financial products selection process [online], [accessed 2013-08-07]. Available on the Internet: http://www.lb.lt/n20341/tyrimo_skaidres.pdf

Bank of Lithuania. 2012. Quick credits market review [online], [accessed 2013-08-02]. Available on the Internet: http:// www.lb.lt/apzvalga_2

Bank of Lithuania. 2013. Households Financial Behaviour Survey Review [online], [accessed 2013-08-07]. Available on the Internet: http://www.lb.lt/namu_ukiu_finansines_elgsenos_ apklausos_apzvalga_2013_nr_1

Barigozzi, M., et al. 2009. The distribution of households comsumption-expenditure budget shares, European Central Bank, Working Paper Series 1061: 22-39.

Charupat, N.; Huang, H.; Milevsky, M. A. 2012. Strategic financial planning over the lifecycle. A conceptual approach to personal risk management. London: Blackwell. http://dx.doi.org/10.1017/CBO9780511807336
Gambacorta, L.; Marques-Ibanez, D. 2011. The bank lending channel: Lessons from the crisis, Bank of Internation Settlements Working Papers 345: 39-51.

Gudaitis, T. 2009. Research of Lithuanian pension system's reform: from conception to first annuities, Management of Organizations: Systematic Research 49: 37-56.

Klimavičienè, A.; Jurevicienė, D. 2008. Asmeninių finansų valdymo teoriniai aspektai gyvenimo ciklo požiūriu, Business: Theory and Practice 9(1): 22-32.

Krajnakova, E.; Vojtovic, S. 2011. Economic development of science and education among the priorities of state. Efficiency and responsibility in education. Praha: CZU.

Lithuanian Department of Statistics 2013 [online], [accessed 2013-08-06]. Available on the Internet: http://osp.stat.gov. lt/pranesimai-spau dai?articleId $=1064140$

Lusardi, A. 2008. Household Saving Behavior: The Role of Financial Literacy, Information and Financial Education Programs. London: Blackwell. http://dx.doi.org/10.3386/w13824

Lusardi, A.; Mitchell, O. S.; Curto, V. 2010. Financial literacy among the young: evidence and implications for consumer policy, The Journal of Consumer Affairs 44(2): 20-39. http://dx.doi.org/10.1111/j.1745-6606.2010.01173.x

Lusardi, A.; Mitchell, S. O. 2013. The Economic Importance of Financial Literacy: Theory and Evidence. London: Blackwell. http://dx.doi.org/10.3386/w18952

Landerretche, O.; Martínez, A. C. 2011. Volutary Savings, Financial Behavior and Pension Finance Literacy: Evidence from Chile. London: Blackwell.

Marcolin, S.; Abraham, A. 2006. Financial literacy research: current literature and future opportunities, in 3rd International Conference on Contemporary Business.

Rakauskienè, O. G.; Bikas, E. 2007. Lietuvos gyventojų santaupos: moterų ir vyrų taupymo elgsenos modeliai, Ekonomika 79: 125-140.

Ruškyte, D.; Rutkauskas, A. V.; Navickas, V. 2013. Mokesčių ir socialinio draudimo įmokų masto ir struktūros ittakos darbo rinkai vertinimas pasitelkiant stochastiškai informatyvią ekspertinę sistemą, Business: Theory and Practice 14(2): 83-96.

van Rooij, M.; Lusardi, A.; Alessie, R. J. 2011. Financial literacy, retirement planning and household wealth. London: Blackwell. http://dx.doi.org/10.3386/w17339

Taujanskaitè, K.; Jurevicienè, D. 2010. Asmeninių finansų valdymo ypatumai ekonominio nestabilumo sąlygomis, Mokslas - Lietuvos ateitis 2(2): 104-111.

Mykolas NAVICKAS. Student of economics in ISM University of Management and Economics. Author of 2 scientific publications. Spheres of interests: financial literacy, personal finance, microeconomics, macroeconomics, international economics, corporate philanthropy.

Tadas GUDAITIS. Doctor of social sciences (economics), Associate Professor at International Business School at Vilnius University. Author of more than 10 scientific publications published in Lithuania and abroad. Currently author is making postdoctoral research "Life-Cycle funds system simulation model development and implementation in defined contributions pension accumulation system in Lithuania". Postdoctoral fellowship is being funded by European Union Structural Funds project "Postdoctoral Fellowship Implementation in Lithuania". Spheres of interests: social economics, old-age pension systems, pension funds, personal finance management, financial literacy. 
Emília KRAJNAKOVA. Doctor of social sciences, Assoc. Professor at University of Alexander Dubcek in Trencin, the Faculty of social-economic relations, the Department of management and development of human resources.

Author of more than 120 scientific publications, published domestically and abroad (Czech Republic, Germany, Poland, Russia, Serbia). Spheres of interests: financial literacy, labour market, economic sociology, human resources management, employment policy, social mobility, migration.

This work was partly supported by project "Promotion of Student Scientific Activities" (VP1-3.1-ŠMM-01-V-02-003) from the Research Council of Lithuania (Mykolas Navickas). This project is funded by the Republic of Lithuania and European Social Fund under the 2007-2013 Human Resources Development Operational Programme’s priority 3. 